\title{
The Representation of Women's Status in Domestic and Political Patriarchy in Mary Astell and Mary Wollstonecraft
}

La représentation du statut des femmes dans le patriarcat domestique et politique chez Mary Astell et chez Mary Wollstonecraft

\section{Guyonne Leduc}

\section{OpenEdition \\ Journals}

\section{Electronic version}

URL: http://journals.openedition.org/rfcb/6108

ISSN: 2429-4373

\section{Publisher}

CRECIB - Centre de recherche et d'études en civilisation britannique

\section{Printed version}

Date of publication: 1 June 2010

ISSN: 0248-9015

Electronic reference

Guyonne Leduc, "The Representation of Women's Status in Domestic and Political Patriarchy in Mary Astell and Mary Wollstonecraft", Revue Française de Civilisation Britannique [Online], XV-4 | 2010, Online since 01 June 2010, connection on 07 January 2021. URL: http://journals.openedition.org/rfcb/6108

This text was automatically generated on 7 January 2021.

\section{c) (†) $\odot$}

Revue française de civilisation britannique est mis à disposition selon les termes de la licence Creative Commons Attribution - Pas d'Utilisation Commerciale - Pas de Modification 4.0 International. 


\title{
The Representation of Women's Status in Domestic and Political Patriarchy in Mary Astell and Mary Wollstonecraft
}

\author{
La représentation du statut des femmes dans le patriarcat domestique et \\ politique chez Mary Astell et chez Mary Wollstonecraft
}

Guyonne Leduc

1 Influenced by Descartes, Astell (1666-1731) and Wollstonecraft (1759-1797) see women as reasoning creatures and claim that they should be treated as men are. Astell has attracted, as has Wollstonecraft, but for different reasons, the label of 'the first English feminist. ${ }^{1}$ As Kolbrener observes, their feminisms are contrasted: 'Astell's feminism was still firmly rooted in conservative political commitments and the language of the High Church' whereas Wollstonecraft's was 'based upon rights and natural liberty.'

2 Both writers were politically committed, denouncing women's status and submission, and criticizing many aspects of patriarchy which Fletcher defines as 'the institutionalised male dominance over women and children in the family and the subordination of women in society in general. ${ }^{4}$ There is an analogy between the family (microcosm) and the state (macrocosm) as Smith clearly explains: 'Monarchical theory, outlined most thoroughly by Robert Filmer [Patriarcha (1680)], stressed authority flowing from a natural, God-ordained patriarchal principle. As the father ruled his family and household at God's will, so the king held sway over his larger, national family. ${ }^{5}$ The patriarchal analogy between the family and the state implies a parallel between the domestic microcosm of the family (with the husband's authority over his wife, the father's over his children and the master's over his servants) and the political macrocosm of the state (the king's authority over his subjects).

3 The analogy is complemented by the "patriarchal opposition between the "public" (economy/ state) and the "private" (domestic, conjugal and intimate life). ${ }^{6}$ Domestic patriarchy refers to 
the submission of women, the final aim of their education being marriage, sometimes for economic survival, but always as a means of domestic patriarchy to maintain a 'patrilineal system of property inheritance.'7 Political patriarchy coupled with the social contract implies not only the absence of women's involvement in political life but also the absence of their civil existence.

4 Astell and Wollstonecraft deal with the representation of women's status in domestic and political patriarchy as constructive, and proposing, thinkers. Their apparent challenge to patriarchal society reflects their ambition to give enlightened women a better and more equal place. This paper deals with women's subjection in the household and in the state, linking rather than distinguishing the public and the private spheres. After a presentation of the writers and their works highlighting their common points and differences, the analysis of both writers' representations of women's status in domestic and political patriarchy will focus on particular aspects in law and social practices such as education and marriage. Finally we will turn to the constructive side of criticism: for both Astell and Wollstonecraft, women should be educated not to conform 'to the figure of the woman sculpted by masculine desire' to use Sharrock's words, ${ }^{8}$ but as rational creatures.

\section{Astell and Wollstonecraft, writers committed to women's interests}

5 No filiation can be established between Astell and Wollstonecraft. No proof exists that the latter had read any of the former's writing. Astell was born in Newcastle into the gentry. Up to the age of 13 she was educated by her uncle. After her parents' deaths, she moved to London at about the age of 21 and began her career as a writer. Her Serious Proposal to the Ladies (1694) made her famous overnight and attracted the attention of several women patrons who gave her financial support. She set up a charity school for girls in Chelsea in 1709 and spent the final years of her life in London. Wollstonecraft was born in the capital in 1759; her father was a middle-class gentleman farmer. From the age of 19, she 'worked in all of the traditional genteel female employments. ${ }^{9}$ She was the paid companion of a widow before founding two day schools, then becoming a governess. Thereafter, " $[s]$ he became first a translator and reader, afterwards a reviewer and editorial assistant ${ }^{10}$ to a journal, supporting herself by writing.

The two women's writings belong to different historical contexts yet 'both wrote in response to political revolutions. ${ }^{11}$ Astell lived after the Civil War and the Glorious Revolution which led to the questioning of all authority in society and in the family, resulting in a crisis both in political and in gender relations. Wollstonecraft was writing in reaction to the French Revolution, which is 'essential in order to understand [her] feminist challenge to English conservatism. ${ }^{12}$ For McCrystal, '[their] revolutionary discourse deals at once with political revolution - of subjects against rulers - and with a kind of sexual revolution: of women against men. ${ }^{13}$

7 Astell advocated passive obedience; Wollstonecraft wanted to change society. Both wanted women to obtain the right to think and to speak, the latter also wanting them to have a civil existence. Astell was 'the first woman to denounce Locke's politico-sociological positioning of women and wives. ${ }^{14}$ Wollstonecraft is deemed 'the first modern feminist theorist ${ }^{15}$ even if, before her Vindication, works dealt with women's roles and rights. 
What is new in her work, Brody stresses, is her 'criticism of the social and economic system which created a double standard of excellence for male and female and relegated women to an inferior status. ${ }^{16}$

8 Both writers were committed to women's interests. In her first Proposal Astell defines herself as 'A lover of her sex' with an intellectual and spiritual ambition for women. '[A]mbition' and 'improvement' are keywords in her commitment expressed in the opening pages of her first Proposal. ${ }^{17}$ Likewise, Wollstonecraft states at the beginning of her 'Dedication': 'I plead for my sex, not for myself,' ${ }^{18}$ which follows two similar assertions in her 'Introduction' ( $V$ 81-82, 82). Both Astell and Wollstonecraft wanted to make women aware of their capacities and of their worth, to lead them to self-esteem (instead of interiorizing a so-called inferiority) and distinguish essence (the life of the mind and the soul for a better life) from appearances (the care of one's body). Both share the conviction that women do not have to repress their intellect and that independence is necessary, yet not in the same fields: Astell intellectually, emotionally and, in Wollstonecraft's case, one can add economically ( $V$ 85).

9 Both were in favour of women's education and against their exclusion from knowledge. Astell advocated individual spiritual and moral reformation extending it to others through good examples ( $P$ 41) and would agree with Wollstonecraft's aim: 'It is time to effect a revolution in female manners - time to restore to them their lost dignity ...' (V 133). The latter looked for a reformation not only of women but of the whole of society in keeping with the radical dimension of her ideas. This is why Sapiro refers to the liberal quality of her ideas: 'One reading of the book is that it called for extending the 'rights of man' to women . . . ${ }^{19}$ while Kinnaird stresses, Astell's prefeminism 'was not born of liberal impulses but of conservative values. She preached not women's rights but women's duties ...' ${ }^{20}$ Both women, however, advocate 'the dignity of women, educational reform, and the ideal of companionate marriage. ${ }^{21}$

10 Several works will be considered here. Astell's Serious Proposal (1694) claims that women should be treated as men are. It argues in favour of creating a college of higher education for women with a curriculum similar to that studied by men. ${ }^{22}$ Such a college would be a 'religious retreat' ( $P$ 18), for women where unmarried ones might withdraw either temporarily or not; they could later return to the world as governesses. Unlike Wollstonecraft, 'she makes no plea that the universities should admit women as well as men; she never argues that women have as much right as men to enter the professions and take part in the public life of the nation. ${ }^{23}$ As her college was not yet built, the Second Part of the Proposal (1697) provided a method for 'right thinking'24 necessary for women's intellectual emancipation. Reflections on Marriage (1700) denounces the lack of balance of power within a marriage.

11 Wollstonecraft is a "versatile writer. ${ }^{25}$ A Vindication of the Rights of Woman (1792) starts with an address to Talleyrand-Périgord who delivered a report on education to the French National Assembly in 1791. It advocated a national system of education for both sexes of all ages; it however directed girls to domestic duties. As Moore puts it, she appeals to him 'to reconsider his views on female education in the light of the argument she makes for women's intellectual and moral equality ... ${ }^{26}$ Addressed to middle-class women ( $V$ 81), A Vindication was written in response to conduct books for young women that 'have been more anxious to make them alluring mistresses than affectionate wives and rational mothers' ( $V$ 79). She defines it as 'a treatise . . on female rights and manners' (V 79). Nowadays, it is called 'the founding text of Anglo-American feminism' ${ }^{27}$ or 'the feminist 
declaration of independence. ${ }^{28}$ The Wrongs of Woman; or, Maria is her unfinished novel on domestic tyranny with 'intertwined stories [many cases of women's sexual oppression]. The main one is that of Maria Venables, an upper middle-class woman, perfectly sound of mind, committed to an insane asylum by her husband who, in exercising his right to consign Maria to the asylum, separated her from her infant daughter. ${ }^{29}$ As Shanley writes, the novel 'explored the impact of law on creating and perpetuating sexual inequality. Together [with A Vindication] they constituted an extraordinary analysis of both the public and interpersonal workings of patriarchal power. ${ }^{30}$

\section{The representation of women's status in social practices: education and marriage}

12 So as to further the analysis of the two writers' representations of domestic and political patriarchy, something must be first said about how the situation of women evolved between Astell's and Wollstonecraft's time, given the socio-economic context and the long-term political aftermath of the Glorious Revolution. McKeon refers to the socio-economic background in order better to explain women's changing economic situation and increasing submission to patriarchy: 'the separation of the public from the domestic sphere is materially grounded in the capitalist transformation of the English countryside [...]. the emergence of modern patriarchy, and its system of gender difference, cannot be understood apart from the emergence of the modern division of labor and class formation. ${ }^{31}$ Focusing on gender difference, Hill writes, 'the victory of individualism was a victory for property, and wives by their very legal definition were propertyless so that all the Puritan emphasis on the virtues of thrift, industry and discipline tended towards the reinforcement not the weakening of the authority of husband and father. ${ }^{32}$

The socio-economic background was reinforced by the political context. Perry explains how male authority was reasserted after the Glorious Revolution: in theory as well in practice it tightened the reins on women and reaffirmed men's power over them. ${ }^{33}$ The power in the state (limited monarchy) was set apart from the power within the family (absolute monarchy). She argues: 'Locke's statement, then, simultaneously legitimated two related forms of political practice: a limited monarchy responsible to an all-male citizenry in which each member was theorized as an absolute authority within his own family and as independent of any other citizen or household. ${ }^{34}$

The repercussions of these changes on the situation of women are to be understood against the workings of patriarchy in the background. They depend on a conception of woman's inferiority which also means an inferior status in society, resting on limited female education, laws and customs. The system of patriarchy is embodied within the family, by gender roles [wife and mother] partly constructed by education and within the state, by legal and economic structures, such as women's loss of property rights after marriage.

Both writers dismiss the concept of woman's innate inferiority ( $P$ 10). For them, woman's inferior situation is due to external causes, in particular education, which leads to sex differences. Astell develops the responsibility of education: 'if our Nature is spoil'd, instead of being improv'd at first; if from our Infancy we are nurs'd up in Ignorance and Vanity... 'tis not strange that the ill effects of this Conduct appear in all the future Actions of our Lives' ( $P$ 11). Wollstonecraft's arguments follow the same logic: 'a profound conviction 
that the neglected education of my fellow-creatures is the grand source of the misery I deplore, and that women, in particular, are rendered weak and wretched by a variety of concurring causes' (V 79). No divine ordinance can be deciphered in women's inferior status.

This so-called inferiority leads to women's legal subjection. The right of primogeniture is one of the privileges given to the male sex, denounced in the Wrongs of Women (7.125, 128). In common law, husband and wife were 'one person' 35 and marriage meant the 'civil death' of women. ${ }^{36}$ Hence Brody writes: 'A married woman, then, could legally hold no property in her own right, nor enter into any legal contract, nor for that matter claim any rights over her own children. ${ }^{37}$ Wollstonecraft comments upon the fact that a wife is her husband's property both in A Vindication $(V 107,262-63)$ and in Wrongs where at least two sentences uttered by Maria bring the point home: '[a wife] has nothing she can call her own'38 and 'a wife being as much a man's property as his horse, or his ass' (2.11.158). A woman does not even own her own body, as Shanley notes: 'when Venables offers sex with Maria to his friend for a loan of five hundred pounds, both men regard the action as a plausible extension of Venables's prerogative as a husband. ${ }^{39}$ It means that a 'married woman had no legal self in the patriarchal society... 40

Laws are complemented by customs and denounced by both writers in the construction of women's subordination. Wrongs links them in the Preface (73). Astell castigates the force of 'that Tyrant Custom' ( $P$ 15) in connection with education: 'Thus Ignorance and a narrow Education, lay the Foundation of Vice, and Imitation and Custom rear it up' (P 14). Wollstonecraft associates custom and women's perennial submission $(V 123,262)$.

Customs resulting in women's lack of proper education participate in the construction of female inferiority. Astell would fully agree with Wollstonecraft's assertion that 'everything conspires to render the cultivation of the understanding more difficult in the female than the male world' ( $V$ 145). They both denounce a double standard. Astell calls attention to a vicious circle and men's responsibility: 'Women are from their very infancy debarr'd those advantages with the want of which they are afterwards reproached and nursed up in those vices which will hereafter be upbraided to them' (P 10). Parallel ideas and terms are to be found in A Vindication: 'it is unreasonable, as well as cruel, to upbraid them with faults that can scarcely be avoided...' (V 225). Both writers blame men who encourage ignorance in order to keep women subservient $(P 9, V 80)$.

19 The genteel education given at home by private tutors, or for the upper middle class in boarding schools, consisted in teaching the accomplishments along with reading and writing, stressing appearances over being. Middle-class girls were also taught household management. Astell violently criticizes the importance given to the appearance of their bodies: 'I cannot ... reflect, that those Glorious Temples . . . be like a garnish'd Sepulchre, which for all its glittering, has nothing within but Emptiness and Putrefaction' ( $P$ 7). ${ }^{41} \mathrm{~A}$ hundred years later, Wollstonecraft's denunciation is less scathing: 'genteel women are, literally speaking, slaves to their bodies and glory in their subjection' (V 131).

The aim of such an education is to make women pleasing objects in the eyes of men. Wollstonecraft's comparison is explicit as concerns men's sexual desire that is to be teased by reified women: women were like 'standing dishes to which every glutton may have access' (V 254) while Astell was less virulent, comparing women to 'Tulips in a Garden' ( $P$ 7). What Purkiss writes about Astell can apply to Wollstonecraft: 'Astell is critical of women's representation of their bodies as commodities to be bought and sold, items of display which signify their price in a mercenary marriage market. ${ }^{42}$ The importance given to 
appearances leads both writers to denounce the vanity of women's conversation and occupations: Astell refers to 'that Meanness of Spirit' (Letters 32-33) and Wollstonecraft to 'the mind [that] is left to rust' (V 174).

21 The resulting risk is twofold. On the one hand, ignorance (including romantic illusions about their future lives) leads to vice for Astell $(P 11,14)$ while for Wollstonecraft $(V$ 156), ignorance is slavery ( $V$ 261-62). On the other hand, a lack of independence of reasoning and judgement will make them bad wives and bad mothers ( $P$ 40, 42, V 119, $137)$, that is, a 'nuisance' for society, in Astell's words ( $P 10)$. For both writers, 'an educated mother is a better one' (P 40, 41-42, V 113, 137, 139, 272). ${ }^{43}$

Both are angry women, denouncing women's subjection in society, criticizing fellow women above all as victims of their environment and their limited education. Françoise Barret-Ducrocq stresses that women 'forge their own chains': 'C'est ... parce qu'on les habitue dès l'enfance à forger leurs propres chaînes qu'elles prennent pour naturel ce qui n'est que le produit de leur formation. Le goût des poupées, par exemple, ou l'amour des beaux atours..." ${ }^{44}$ She adds: 'Le conditionnement, auquel elles sont soumises ... fait de la majorité d'entre elles, du moins, dans les classes aisées, des infirmes de la raison. ${ }^{45}$ She refers to Wollstonecraft's own condemnation: 'Whilst they are absolutely dependent on their husbands, they will be cunning, mean, selfish ...' (V 258).

Secondly, both writers vituperate women not just as victims, but also as accomplices in their own fate, when they are not held responsible, or even as guilty, manipulators, drawing advantages from the inferiority they contribute to creating; women use appearances, 'the great art of pleasing' ( $V$ 111) so as to gain a so-called share of power ( $V$ 126). Wollstonecraft draws a further conclusion: 'Women, obtaining power by unjust means, by practising or fostering vice . . become either abject slaves or capricious tyrants' ( $V$ 133). Both writers are very critical of women, accusing them overtly in a misogynistic tone: Astell challenges them to submit: 'How can you be content to be in the World like Tulips in a Garden, to make a fine shew and be good for nothing?' (P 7) and Wollstonecraft writes 'It is your own conduct, O ye foolish women! which throws an odium on your sex' (V 309).

Such charges seek to force women to see their 'real Interest' ( $P$ 6, V 135), that is to cultivate their minds for the life to come, as Astell writes, playing on women's vanity to better describe her project: '[The] aim is to fix that Beauty, to make it lasting and permanent ... and to place it out of the reach of Sickness and Old Age, by transferring it from a corruptible Body to an immortal Soul' ( $P$ 5). She wants to free women from the tyranny of appearances and ignorance so that they 'might realize in their traditional sphere their full potential as wives, mothers, and teachers of the young, ${ }^{146}$ a threefold aim with which Wollstonecraft would have agreed. The latter fights against what Poston calls the 'erasure of the female self ${ }^{47}$ when she writes 'I do not wish them to have power over men; but over themselves' ( $V$ 156), which is exactly what Astell meant when she wrote: 'our only endeavour shall be to be absolute Monarch in our own Bosoms' ( $P$ 180). Both writers want their works to be incentives to convince women that, as reasoning creatures, they should reject their interiorized sense of inferiority.

Apart from education, marriage is another target of their criticisms. Some key elements concerning that institution in the early modern period must be borne in mind. Sommerville recalls that 'any woman who wanted to marry was morally obliged to accept subjection to her husband as part of the divine institution of marriage. ${ }^{38}$ Astell is quite in keeping with these ideas when she asserts that husbands like kings are 'the representatives of God'49 and likewise, '[s]he then who Marrys ought to lay it down for an 
indisputable Maxim that her Husband must govern absolutely and intirely, and that she has nothing else to do but Please and Obey' ( $R$ 62). Astell justifies the wife's obedience to her husband in terms of her submission for 'GOD's sake' ( $R$ 75); she would obey not her husband but God. Astell refers to marriage as a sacrament, presented in heavenly terms ( $R$ 36) and not as a contract implying the free consent between people. ${ }^{50}$ She cannot agree with Locke whose 'social contract,' in Bryson's words, 'constitutes the political realm of men, while the marriage contract governs the private world of women."51 She 'strongly disagrees with this contractual account of the natural authority, ${ }^{152}$ writing in Reflections: 'Covenants betwixt Husband and Wife, like Laws in an Arbitrary Government, are of little Force, the Will of the Sovereign is all in all' ( $R$ 106). For her, men are not free but depend on God's authority: therefore, they are not free to sign a contract, to give someone else what they do not own. Unlike Astell, Wollstonecraft defends a whig view of marriage, writing: 'The divine right of husbands, like the divine right of kings, may, it is to be hoped, in this enlightened age, be contested without danger ...' (V 128).

They both supported the religious institution of marriage. For Astell, the marriage bond was sacred; Wollstonecraft also supported marriage (V 167) as Shapiro puts it: [she] believed strongly in the institution of marriage, as long as it was founded on the correct principles of affection based on respect. ${ }^{53}$ Yet both women scathingly criticized its practice. Comparisons and metaphors are eloquent: a wife is called an 'upper servant' $(R 78, V 127$, 169). Marriage is considered as prostitution in the context of the marriage market by Astell (P 39) and as a whole by Wollstonecraft $(V 152,168)$ who also describes it as 'legal prostitution to increase wealth or shun poverty. ${ }^{54}$ She chooses slavery as 'a suitable metaphor for the oppressed state of a wife' ( $V$ 276); ${ }^{55}$ marriage is even depicted as the archetypal prison in Wrongs: 'Marriage had bastilled me for life' (2.10.154-55).

Both authors suggest unhappy marriages may have potential benefits. For Astell, a wife has two solutions either submission or religious devotion, as is stressed in the closing sentence of Reflections: 'if any Woman think her self Injur'd, she has a Remedy in reserve which few Man will Envy or endeavour to Rob her of, the Exercise and Improvement of her Vertue here, and the Reward of it hereafter' ( $R$ 80). Through submission women can show 'their inherent moral superiority. ${ }^{56}$ Unhappy marriages can even prepare 'long-suffering women for sainthood ${ }^{157}$ as one's soul can improve through trial, to which marriage is assimilated ( $R$ 131). For Wollstonecraft, the mistreated wife can become a better mother for 'an unhappy marriage is often very advantageous to a family, and [...] the neglected wife is, in general, the best mother' (V 114-15).

\section{Astell and Wollstonecraft's purpose: to educate women as rational creatures}

The constructive aspect of their criticism is clear in both writers' texts. Both defend men's and women's innate intellectual equivalence based on rationality. Women's socalled mental and physical inferiority takes its roots in the traditional interpretation of the Bible. Astell speaks out against such a tradition. For example, she argues: 'For since God has given Women as well as Men intelligent Souls, why should they be forbidden to improve them?' (P 22). Both acknowledge women's inferior physical strength: Wollstonecraft writes: 'the female in point of strength is, in general, inferior to the male. This is the law of Nature' ( $V$ 80). Yet men's strength did not, for her, mean strength of mind. 

religious arguments to prove this. Astell takes her arguments from Genesis saying that men and women were created in God's image and gifted with reason ( $P$ 22). Her assertion is reinforced by another in her second Proposal: 'GoD does nothing in vain, he gives not Power of Faculty which he has not allotted to some proportionate use, if therefore he has given to Mankind a Rational Mind, every individual Understanding ought to be employ'd in somewhat worthy of it' ( $P$ 118). Reason has not been granted to women without any purpose. Wollstonecraft agrees with this twofold argument. One finds a question in her text similar to Astell's: 'the nature of reason must be the same in all, if it be an emanation of divinity, the tie that connects the creature with the Creator; for, can that soul be stamped with the heavenly image, that is not perfected by the exercise of its own reason?' (V 143).

women are seen to be gifted with reason, this should therefore be improved: women have to develop their talents as a duty to themselves and to God for both writers ( $P$ 22, $V$ 143). The parable of the talents is implicitly hinted at by Astell (P 39) and explicitly by Wollstonecraft ( $V$ 140). That 'power of improvement' ( $V$ 143) is complemented by understanding for Wollstonecraft ( $V$ 156). Improvement so as to develop intellectual and spiritual liberty would not be possible without a proper education.

Both refer to the aim of women's lives which is not to be but pleasing objects and men's slaves, an affront to God. Astell refers to God's design: 'What did we come into World for? To Eat and to Drink and to pursue the little Impertinences of this Life? Surely no, our Wise Creator has Nobler Ends whatever we have; He sent us hither to pass our Probation, to Prepare our selves and be Candidates for Eternal Happiness in a better.' $(P$ 88). Wollstonecraft asks a parallel rhetorical question about the aim of a woman's earthly life. After an assertion ('I will take for granted, she was not created merely to be the solace of man, and the sexual should not destroy the human character' [V 143-44; see also 138, 156]), she addresses a direct question to God the creator: 'hast thou created such a being as woman, who can trace Thy wisdom in Thy works, and feel that Thou alone art by Thy nature exalted above her, for no better purpose... [than] to submit to man, her equal ... ? Can she consent to be occupied merely to please him ... when her soul is capable of rising to Thee?' (V 162). Both writers provide rational arguments and also rely on theology to argue that one has to improve and prepare for life in the next world through activities in this world (including being good mothers and, Wollstonecraft would add, good citizens).

and education are necessary so as to discharge one's duties (to oneself, to one's family and to the community) as Wollstonecraft points out $(V 155-56,158)$. Both writers acknowledge differences in men's and women's tasks ( $P$ 149-50, V 260). What Shanley writes about Wollstonecraft can also be applied to Astell: 'she accepted the notion that one of women's primary roles and social contributions ... was nurturing and raising children. ${ }^{58}$

If better female education is indispensable, what does better education mean? First of all it means the autonomy of women's thought based on an awareness of their worth and self-esteem. Astell developed a method to teach women how to think. No such element is suggested by Wollstonecraft. Women's intellectual autonomy is a means of becoming independent of others' opinions. Astell stresses the destructive importance given to others' opinions: 'We value them too much, and our selves too little, if we place any part of our desert in their Opinions, and do not think our selves capable of Nobler Things than the pitiful Conquest of a worthless heart' ( $P$ 8).

34 Both writers refer to the authority of reason and the autonomy of the mind. For Astell, 'The Mind is free, nothing but Reason can oblige it, 'tis out of the reach of the most absolute

Revue Française de Civilisation Britannique, XV-4 | 2010 
Tyrant' ( $R$ 56) while Wollstonecraft writes: 'they [women] must only bow to the authority of reason, instead of being the modest slaves of opinion' ( $V$ 139). Wollstonecraft's ideas are quite in keeping with an emancipation from the patriarchal system (V 135).

Time should be taken before marriage to give women a better education. Astell emphasizes its import: 'a discreet and vertuous Gentlewoman will make a better Wife than she whose mind is empty tho' her Purse be full' ( $P 40)$, personal qualities being more important than material wealth. Likewise, in Thoughts on the Education of Daughters, Wollstonecraft refers to 'early marriages' as 'a stop to improvement ${ }^{59}$ and 'wanted to delay [them] so that women could have time to develop their understandings. ${ }^{60}$

A better education would lead first to a better choice of one's husband. Astell rejects any forced marriage (P 39). Since a woman, she writes, '[e]lects a Monarch for Life' ( $R$ 43), women's choice should rely on reason, not appearances or appetites ( $P$ 39). She advocates kindness, esteem and friendship, the ideal of her academy, as the basis for marriage. A similar conception is expressed by Wollstonecraft: 'they [women] should not be led astray by the qualities of a lover - for as a lover the husband, even supposing him to be wise and virtuous, cannot long remain' ( $V$ 228). She condemns such a foolish attitude (romantic and sexual love) in the choice of a marriage partner and advocates 'supportive friendships over promiscuous sexual relationships ... ${ }^{61}$ as the basis for relations between husband and wife (V 113-15, 169-70, 243, 272).

Two positive long-term consequences could appear. First, Astell considers the possibility of the recovered dignity of marriage if the husband is enlightened ( $R$ 132). Second, for Wollstonecraft, love would be a more noble feeling: 'even love would acquire more serious dignity, and be purified in its own fires ...' (V 227). Thus both advocate 'a new kind of marriage ${ }^{\prime 62}$ with improved relations between the sexes. As to Astell's ideas here, Kinnaird refers to 'an enlightened ideal of marriage as rational and companionate, ${ }^{63}$ which could be equally well applied to Wollstonecraft who uses the word 'companions' ('agreeable or rational companions' [V 202]).

Educating women is an imperative to prepare them for their duties in married life. With this in mind, Wollstonecraft recalls the consequences of a lack of proper education: 'Do the women who, by the attainment of a few superficial accomplishments, have strengthened the prevailing prejudice, merely contribute to the happiness of their husbands?' ( $V$ 119). Education should enable a wife to be a companion, a 'helpmate' ( $V$ 139, 268). Wollstonecraft establishes a link between wives' and mothers' characters: 'have women who have early imbibed notions of passive obedience, sufficient character to manage a family or educate children?' (V 119, see also 168, 272). She refers to independence of mind and character in the contrasting portraits of good and bad mothers, portraits drawn when two wives are left widows. The uneducated woman becomes in turn unable to educate her children ( $V$ 136-37). The reverse, ' $a$ woman with a tolerable understanding' ( $V$ 137), properly educated, will prove a good mother ( $V$ 272). It will lead to 'enlightened maternal affection' (V 271).

Both writers consider attention given to young children as a short-term duty. Kinnaird writes: 'she [Astell] urged women to nurse their infants and watch over their children in their formative years. ${ }^{64}$ The influence of Locke's Some Thoughts Concerning Education may perhaps be detected in the heed that should be paid to infants and young children. Wollstonecraft also refers to 'the care of children in their infancy' ( $V$ 271) and conjures up the suckling mother $(V 227,259,323)$. Both writers see women endowed with a longterm mission in relation to their families and society. Astell refers to a civil mission and 
a moral one ( $P$ 150). An educated woman's task was 'to revive the ancient Spirit of Piety in the World and to transmit it to succeeding Generations' ( $P$ 18) whereas Wollstonecraft refers more generally 'to reform [ing] the world' ( $V$ 133). They both think of women's roles not only in their families but also in the community (P 151-52, V 265).

Women's independence for Astell was essentially intellectual and spiritual, not as clearly economic as for Wollstonecraft, perhaps because they did not address the same social strata and because women's socio-economic situation had evolved. Both Astell and Wollstonecraft argue that being able to support oneself would provide an alternative to marriage as a means of economic survival. For Astell, single women leaving her 'monastery' could become governesses $(P 24,39)$ and be as useful as mothers ( $P$ 150). She did not advocate women's access to professions as she knew that was impossible in her time but she hoped it would no longer be impossible in the future (R 75).

41 For Wollstonecraft, independence was indispensable; it also resulted from the ability to support oneself ( $V$ 268). She saw economic autonomy as necessary for single women, referring to 'the bitter bread of dependence' ( $V$ 160) for those who became a burden on their families. ${ }^{65}$ Such was also the case for wives who sought to be independent from their husbands; without such independence, as Shanley writes: 'husbands and wives could not experience the kind of equality that Wollstonecraft saw as a prerequisite for 'friendship' within marriage. ${ }^{66}$ Yet she does not forget to add that for the author a job is not compulsory. Wollstonecraft refers to a range of possibilities available to women (not ladies): practising physicians, farmers, shop keepers ( $V$ 266-68); they might also be interested in business, politics and history.

Having a job would give women a civil existence not as subordinated wives and mothers in private life, but as individuals participating in society, in the state, which would lead to questioning the separation of the private and public spheres. For both women, contrary to the prevailing ideology of patriarchy, there is continuity between 'the domestic life' of the family and 'the political life of the state. ${ }^{17}$ Astell denounced a double standard: why accept in the family what is not accepted in the state, that is a tyrant $(R 17,18-19,46-47)$ ? Concerning Wollstonecraft's writings, Todd stresses that 'it is this which seems most revolutionary: an insistence that private and public are joined and, [that] long before the 1960s, the personal and political are one' as the feminist Kate Millett put it, ${ }^{68}$ 'to deny the political aspect of familial relations was to curb those of women's rights which were external to the family, ${ }^{16}$ in the 1960 s. To avoid anachronism, one must bear in mind that, as women, Astell and Wollstonecraft were excluded from men's political or social contracts.

The two writers' arguments are often complementary when they are not similar. Some of Astell's ideas reappeared in Wollstonecraft's works, in particular those on the education of women as rational beings which, for Astell and Wollstonecraft, is the key to personal and social progress. It is a right of women and, for Wollstonecraft, it is even 'a social imperative. ${ }^{70}$ Astell does not explicitly refer to women's rights (civil, property or political rights) beyond intellectual autonomy and education contrary to Wollstonecraft. Both hint at or refer to natural rights.

44 A tension can be observed in both writers' representations of patriarchy. Astell advocates women's independence, in particular in Proposal, even though she has to note women's submission as wives in Reflections. There is perhaps an opposition, as Hill observes, between 'her attachment to the divine right of kings and passive obedience' and 'her 
reluctance to accept women's position as slaves to domestic tyranny, ${ }^{71}$ when she writes 'by how much 100,000 Tyrants are worse than one' ( $R$ 17). She can understand and does not condemn women's rebellion against tyrannical husbands ( $R$ 78-79). Even so, she does not accept such rebellion, still less does she encourage it since a woman has to obey her husband behind whom she sees God.

Astell explains how a husband should govern his household: 'Not as an absolute Lord and Master, with an Arbitrary and Tyrannical sway, but as reason Governs and Conducts a Man, by proposing what is Just and Fit' ( $R$ 132). Here she draws the portrait of the enlightened husband. In addition, she does not hesitate to advocate celibacy if conditions are not fulfilled for an enlightened marriage since her alternative for women is either to 'patiently suffer what she cannot cure' $(R 75)$ or 'never consent to be a Wife' $(R 75)$. If a woman does not agree to 'Please and Obey' ( $R$ 62), to be an 'upper servant' ( $R$ 78), a 'slave' ( $R 44,57$, $58,65,76)$ in marriage, which means 'an intire Submission for Life' and 'a continual martyrdom' ( $R$ 78), she had better stay single. What is to be hoped for in Astell as well as in Wollstonecraft ( $V$ 228-29) is that, when women are educated, they will choose their husbands more carefully $(R 74)$, leading to women's better situation in the domestic patriarchy.

In Wollstonecraft's case, the tension lies between the domestic role of 'rational motherhood"72 and personal achievement in public life. She applies to women what Bacon writes about men; she quotes him: 'Certainly the best works, and of greatest merit for the public, have proceeded from the unmarried or childless men' ( $V$ 157) and adds 'I say the same of women,' yet she does not advocate celibacy for women, at least not for the same reasons as Astell. As a compromise she distinguishes two categories of women: 'though I consider that women in the common walks of life are called to fulfil the duties of wives and mothers, by religion and reason, I cannot help lamenting, that women of a superiour cast have not a road open by which they can pursue more extensive plans of usefulness and independence' ( $V$ 228).

The continuity between domestic and public domains (with a cross-influence) is clearly stated in a sentence that encapsulates her hope: 'Would men but generously snap our chains, and be content with rational fellowship instead of slavish obedience, they would find us more observant daughters, more affectionate sisters, more faithful wives, more reasonable mothers - in a word, better citizens' ( $V$ 231). The personal and the political are closely linked when she writes near the end of her book: 'Make women rational creatures and free citizens, and they will quickly become good wives and mothers - that is, if men do not neglect the duties of husbands and fathers' ( $V$ 306). As with Astell, men should be first enlightened to make such a situation possible. The personal and the political would be more tightly connected as, for her, women, as mothers of future citizens, ought to be represented in politics ( $V$ 228). Audacity does not reside in the personal, in celibacy, but in the political field. 


\section{BIBLIOGRAPHY}

ASTELL, Mary. A Serious Proposal to the Ladies. Parts I and II, 1694, 1697, ed. Patricia SPRINGBORG, London: Pickering, 1997.

ASTELL, Mary Some Reflections upon Marriage, Occasion'd by the Duke \& Dutchess of Mazarine's Case; Which Is Also Consider'd, 1700, in Patricia SPRINGBORG (ed.), Astell. Political Writings, Cambridge: Cambridge UP, 1996.

ASTELL, Mary. Mary Astell. The First English Feminist, ed. Bridget HILL, Aldershot: Gower, 1986.

DEFOE, Daniel. An Essay upon Projects, 1697, ed. Henry Morley, London: Cassell, 1887.

LOCKE, John. Two Treatises of Government. 1690, ed. Peter Laslett, Cambridge: Cambridge UP, 1988. SWIFT, Jonathan. A Letter to a Young Lady, on Her Marriage, 1723, Irish Tracts 1720-1723 and Sermons, The Prose Writings of Jonathan Swift, ed. Louis Landa, 14 vols., Oxford: Blackwell, 1948, 9: pp. 83-94. WOLLSTONECRAFT, Mary. A Vindication of the Rights of Woman, 1792, ed. Miriam BRODY. Harmondsworth: Penguin, 1992.

WOLLSTONECRAFT, Mary. The Wrongs of Woman, or; Maria. A Fragment in Two Volumes, 1798, in Gary KELLY (ed.), Mary and The Wrongs of Woman, 1976, Oxford: Oxford UP, 1980.

WOLLSTONECRAFT, Mary. Thoughts on the Education of Daughters, 1787, in Janet TODD and Marilyn BUTLER (gen. eds.), The Works of Mary Wollstonecraft, 7 vols., London: William Pickering, 1989, vol. 4, pp. 1-49.

\section{$* * * * *$}

BARRET-DUCROCQ, Françoise. 'Une Percée conceptuelle dans le champ philosophique: Mary Wollstonecraft pense la différence des sexes,' Cercles, ${ }^{\circ} 4$, 2002, pp. 319-45.

BRODY, Miriam. 'Mary Wollstonecraft: Sexuality and Women's Rights (17590-1797)', Brody, in Dale SPENDER, Feminist Theorists: Three Centuries of Women's Intellectual Traditions, London: Women's Press Ltd, 1983, pp. 40-59.

BROWNE, Alice. The Eighteenth-Century Feminist Mind, Detroit: Wayne State UP, 1987.

BRYSON, Cynthia B. 'Mary Astell: Defender of the "Disembodied Mind," Hypathia, vol. 13, n 4, 1998, pp. 40-62.

FLETCHER, Anthony. Gender, Sex, and Subordination in England 1500-1800, New Haven: Yale UP, 1995.

HILL, Bridget. Women Alone: Spinsters in England 1660-1850, New Haven: Yale UP, 2001.

KAPLAN, Cora. 'Wild Nights: Pleasure/Sexuality/Feminism,' Sea Changes: Culture and Feminism, London: Verso, 1986, pp. 31-56.

KINNAIRD, Joan. 'Mary Astell and the Conservative Contribution to English Feminism,' Journal of British Studies, n 19, 1979, pp. 53-75.

KOLBRENER, William. 'Gendering the Modern: Mary Astell's Feminist Historiography,' The Eighteenth Century, vol. 44, ${ }^{\circ}$ 1, 2003, pp. 1-24.

LEDUC, Guyonne. 'Mary Astell and Daniel Defoe, auteurs de projets féministes pour l'éducation?,' in LEDUC (ed.), L'Éducation des femmes en Europe et en Amérique du Nord de la Renaissance à 1848, Paris: L'Harmattan, 'Des idées et des femmes,' 1997, pp. 144-59. 
MCCRYSTAL, John. 'Revolting Women: The Use of Revolutionary Discourse in Mary Astell and Mary Wollstonecraft Compared,' History of Political Thought, vol. 14, n², 1993, pp. 189-203.

McKEON, Michael. 'Historicizing Patriarchy: The Emergence of Gender Difference in England, 1660-1760,' Eighteenth-Century Studies, vol. 28, nº3, 1995, pp. 295-322.

MILLETT, Kate. Sexual Politics, New York: Doubleday, 1970.

MOORE, Jane. Mary Wollstonecraft, Plymouth: Northcote House, 1999.

PATEMAN, Carole. The Disorder of Women: Democracy, Feminism and Political Theory, Cambridge: Polity Press, 1989.

PERRY, Ruth. 'Mary Astell and the Feminist Critique of Possessive Individualism,' EighteenthCentury Studies, vol. 23, n 4, 1990, pp. 444-457.

POSTON, Carol H. 'Mary Wollstonecraft and "The Body Politic,"' in Maria J. FALCO (ed.), Feminist Interpretations of Mary Wollstonecraft, University Park: The Pennsylvania State UP, 1996, PURKISS, Diane. 'Public Disturbance and Public Speaking: Mary Astell,' Baetyl, n¹, 1993, pp. 33-58.

RAWSON, Claude. 'Swift, les femmes et l'éducation des femmes,' in Guyonne LEDUC (ed.), L'Éducation des femmes en Europe et en Amérique du Nord de la Renaissance à 1848, Paris: L'Harmattan, 'Des idées et des femmes,' 1997, pp. 245-265.

SAPIRO, Virginia. A Vindication of Political Virtue: The Political Theory of Mary Wollstonecraft, Chicago: Chicago UP, 1992.

SHANLEY, Mary Lyndon. 'Marriage Contract and Social Contract in Seventeenth-Century English Political Thought,' The Western Political Quarterly, n 32, 1979, pp. 79-91.

SHANLEY, Mary Lyndon. 'Mary Wollstonecraft on Sensibility, Women's Rights, and Patriarchal Power,' in Hilda L. SMITH (ed.), Women Writers and the Early Modern British Political Tradition, Cambridge: Cambridge UP, 1998, pp. 148-167.

SHARROCK, Catherine. 'De-ciphering Women and De-scribing Authority: The Writings of May Astell,' in Isobel GRUNDY and Susan WISEMAN (eds.), Women, Writing, History, 1640-1740, London: Batsford, 1993, pp. 109-124.

SMITH, Hilda L. Reason's Disciples: Seventeenth-Century English Feminists, Urbana: U of Illinois P, 1982.

SOMMERVILLE, Margaret R. Sex and Subjection: Attitudes to Women in Early-Modern Society, London: Arnold, 1995.

STAVES, Susan. Married Women's Separate Property in England, 1660-1833, Cambridge: Harvard UP, 1990.

STONE STANTON, Kamille. “"Affliction, the Sincerest Friend”: Mary Astell's Philosophy of Women's Superiority through Martyrdom,' Prose Studies, vol. 29, n 1, 2007, pp. 104-14.

TAYLOR, Barbara. 'Mary Wollstonecraft and the Wild Wish of Early Feminism,' History Workshop, $n^{\circ} 3,1992$, pp. 197-219. 


\section{NOTES}

1. John MCCRYSTAL, 'Revolting Women: The Use of Revolutionary Discourse in Mary Astell and Mary Wollstonecraft Compared,' History of Political Thought, vol. 14, n², 1993, p. 189.

2. See Cynthia B. BRYSON, 'Mary Astell: Defender of the "Disembodied Mind,"' Hypathia, vol. 13, $\mathrm{n}^{\circ} 4,1998$, p. 51.

3. William KOLBRENER, 'Gendering the Modern: Mary Astell's Feminist Historiography,' The Eighteenth Century, vol. 44, $\mathrm{n}^{\circ} 1,2003, \mathrm{p} .2$.

4. Anthony FLETCHER, Gender, Sex, and Subordination in England 1500-1800, New Haven: Yale UP, 1995, p. XV.

5. Hilda L. SMITH, Reason's Disciples: Seventeenth-Century English Feminists, Urbana: U of Illinois P, 1982, p. 57.

6. Carole PATEMAN, The Disorder of Women: Democracy, Feminism and Political Theory, Cambridge: Polity Press, 1989, p. 5.

7. Barbara TAYLOR, 'Mary Wollstonecraft and the Wild Wish of Early Feminism,' History Workshop, $\mathrm{n}^{\circ}$ 3, 1992, p. 213.

8. Catherine SHARROCK, 'De-ciphering Women and De-scribing Authority: The Writings of Mary Astell,' in Isobel GRUNDY \& Susan WISEMAN (eds.), Women, Writing, History, 1640-1740, London: Batsford, 1993, p. 117.

9. Miriam BRODY (ed.), A Vindication of the Rights of Woman, 1982, Harmondsworth: Penguin, 1992, p. 4.

10. Marilyn BUTLER, 'General Introduction,' in Janet TODD \& Marilyn BUTLER (gen. eds.), The Works of Mary Wollstonecraft, 7 vols., London: William Pickering, 1989, vol. 1, p. 8.

11. John MCCRYSTAL, 'Revolting Women ...', op. cit., p. 189.

12. Miriam BRODY (ed.), op. cit., p. 21.

13. John MCCRYSTAL, 'Revolting Women ...,' op. cit., p. 189.

14. Cynthia B. BRYSON, 'Mary Astell ..., op. cit., p. 56.

15. Cora KAPLAN, 'Wild Nights: Pleasure/Sexuality/Feminism,' in Sea Changes: Culture and Feminism, London: Verso, 1986, p. 34.

16. Miriam BRODY (ed.), op. cit., p. 25.

17. Mary ASTELL, A Serious Proposal to the Ladies. Parts I and II, 1694, 1697, ed. Patricia SPRINGBORG, London: Pickering, 1997, p. 9. Hereafter included in the text, preceded by $P$.

18. Mary WOLLSTONECRAFT, A Vindication of the Rights of Woman, 1792, ed. Miriam BRODY, p. 85. Hereafter included in the text, preceded by $V$.

19. Virginia SAPIRO, A Vindication of Political Virtue: The Political Theory of Mary Wollstonecraft, Chicago: Chicago UP, 1992, p. 28.

20. Joan KINNAIRD, 'Mary Astell and the Conservative Contribution to English Feminism,' Journal of British Studies, $\mathrm{n}^{\circ}$ 19, 1979, p. 73.

21. Ibid., p. 75.

22. See too Daniel Defoe's 'Academy for women' in An Essay upon Projects, 1697, ed. Henry Morley, London: Cassell, 1887, pp. 171-72 and LEDUC's comparison between Astell's and Defoe's proposals in 'Mary Astell and Daniel Defoe, auteurs de projets féministes pour l'éducation?,' in Guyonne LEDUC (ed.), L'Éducation des femmes en Europe et en Amérique du Nord de la Renaissance à 1848, Paris: L'Harmattan, 'Des idées et des femmes,' 1997, pp. 144-59.

23. Joan KINNAIRD, 'Mary Astell and the Conservative Contribution ...,' op. cit., p. 64.

24. Ibid., p. 62.

25. Mary Lyndon SHANLEY, 'Mary Wollstonecraft on Sensibility, Women's Rights, and Patriarchal Power,' in Hilda L. SMITH (ed.), Women Writers and the Early Modern British Political Tradition, Cambridge: Cambridge UP, 1998, p. 148.

26. Jane MOORE, Mary Wollstonecraft, Plymouth: Northcote House, 1999, p. 37. 
27. Cora KAPLAN, 'Wild Nights ...,' op. cit., p. 34.

28. Miriam BRODY (ed.), p. 1.

29. Mary Lyndon SHANLEY, 'Mary Wollstonecraft on Sensibility ..., ' op. cit., p. 156.

30. Ibid., p. 165.

31. Michael MCKEON, 'Historicizing Patriarchy: The Emergence of Gender Difference in England, 1660-1760,' Eighteenth-Century Studies, vol. 28, n 3, 1995, p. 298.

32. Bridget HILL (ed.), The First English Feminist, Aldershot: Gower, 1986. p. 21.

33. Ruth PERRY, 'Mary Astell and the Feminist Critique of Possessive Individualism,' EighteenthCentury Studies, vol. 23, $\mathrm{n}^{\circ} 4,1990$, p. 449.

34. Ibid., p. 450. Locke writes that 'the Power of a Magistrate over a Subject, may be distinguished from that of a Father over his Children, a Master over his Servant, a Husband over his Wife, and a Lord over his Slave' (Two Treatises of Government, 1690, ed. Peter Laslett, 1960, Cambridge: Cambridge UP, 1988, 2 ch. 1, §2). For Pateman, '[Locke] explicitly agrees with Filmer that [...] that the husband's will must prevail in the household as he is naturally "the abler and the stronger" [Two Treatises $1 \S 47 ; 2 \S 82$ ] '(121).

35. See Susan STAVES, Married Women's Separate Property in England, 1660-1833, Cambridge: Harvard UP, 1990, pp. 1-5, 178-95.

36. Mary Lyndon SHANLEY, 'Marriage Contract and Social Contract in Seventeenth-Century English Political Thought,' The Western Political Quarterly, n 32, 1979, p. 91 (n. 51).

37. Miriam BRODY (ed.), op. cit., p. 30.

38. Mary WOLLSTONECRAFT, The Wrongs of Woman, or; Maria. A Fragment in Two Volumes, 1798, in Gary KELLY (ed.), Mary and The Wrongs of Woman, 1976, Oxford: Oxford UP, 1980, book 2, chapter 11, p. 158.

39. Mary Lyndon SHANLEY, 'Mary Wollstonecraft on Sensibility ..., ,' op. cit., p. 158.

40. Carol H. POSTON, 'Mary Wollstonecraft and "The Body Politic," in Maria J. FALCO (ed.), Feminist Interpretations of Mary Wollstonecraft, University Park: The Pennsylvania State UP, 1996, p. 89.

41. See Jonathan SWIFT's similar observations in A Letter to a Young Lady, on Her Marriage, 1723, Irish Tracts 1720-1723 and Sermons, The Prose Writings of Jonathan Swift, ed. Louis LANDA, 14 vols., Oxford: Blackwell, 1948, 9: 83-94 and Claude RAWSON's article 'Swift, les femmes et l'éducation des femmes,' in Guyonne LEDUC (ed.), L'Éducation des femmes en Europe et en Amérique du Nord de la Renaissance à 1848, pp. 245-65.

42. Diane PURKISS, 'Public Disturbance and Public Speaking: Mary Astell,' Baetyl, n 1, 1993, p. 45.

43. Miriam BRODY (ed.), op. cit., p. 28.

44. Françoise BARRET-DUCROCQ, 'Une Percée conceptuelle dans le champ philosophique: Mary Wollstonecraft pense la différence des sexes,' Cercles, $\mathrm{n}^{\circ}$ 4, 2002, p. 41.

45. Ibid., p. 42.

46. Joan KINNAIRD, 'Mary Astell and the Conservative Contribution ..., op. cit., p. 74.

47. Carol H. POSTON, 'Mary Wollstonecraft and “The Body Politic,"' op. cit., p. 90.

48. Margaret R. SOMMERVILLE, Sex and Subjection: Attitudes to Women in Early-Modern Society, London: Arnold, 1995, p. 217.

49. Mary ASTELL, Some Reflections upon Marriage, Occasion'd by the Duke \& Dutchess of Mazarine's Case; Which Is Also Consider'd, 1700, in Patricia SPRINGBORG (ed.), Astell. Political Writings, Cambridge: Cambridge UP, 1996, pp. 110-11. Hereafter included in the text, preceded by $R$.

50. See John LOCKE, Two Treatises $1 \S 47,2$ §80-83.

51. Ibid., p. 51.

52. Alice BROWNE, The Eighteenth-Century Feminist Mind, Detroit: Wayne State UP, 1987, p. 93.

53. Virginia SAPIRO, A Vindication of Political Virtue, op. cit., p. 144.

54. Mary WOLLSTONECRAFT, A Vindication of the Rights of Men, 1790, in Janet TODD (ed.), Political Writings, Toronto University Press, p. 21. 
55. Jane MOORE, Mary Wollstonecraft, p. 3.

56. Kamille STONE STANTON, “'Affliction, the Sincerest Friend": Mary Astell's Philosophy of Women's Superiority through Martyrdom,' Prose Studies, vol. 29, n 1, 2007, p. 108.

57. Joan KINNAIRD, 'Mary Astell and the Conservative Contribution ...,' op. cit., p. 67.

58. Mary Lyndon SHANLEY, 'Mary Wollstonecraft on Sensibility ..., ' op. cit., pp. 149-50.

59. Mary WOLLSTONECRAFT, Thoughts on the Education of Daughters, 1787, in TODD and BUTLER (gen. eds.), The Works of Mary Wollstonecraft, vol. 4, p. 31.

60. Carol H. POSTON, 'Mary Wollstonecraft and “The Body Politic,"' op. cit., p. 91.

61. TODD (ed.), p. xxiii.

62. Mary Lyndon SHANLEY, 'Mary Wollstonecraft on Sensibility ..., , op. cit., p. 155.

63. KINNAIRD, 'Mary Astell and the Conservative Contribution ..., ' op. cit., p. 72.

64. Ibid., p. 73.

65. See Bridget HILL, Women Alone: Spinsters in England 1660-1850, New Haven: Yale UP, 2001.

66. Mary Lyndon SHANLEY, 'Mary Wollstonecraft on Sensibility ..., ' p. 160.

67. Miriam BRODY, 'Mary Wollstonecraft: Sexuality and Women's Rights (1790-1797)', in Dale SPENDER, Feminist Theorists: Three Centuries of Women's Intellectual Traditions, London: Women's Press Ltd, 1983, 43.

68. TODD, ed., xix. See Kate MILLETT, Sexual Politics, New York: Doubleday, 1970, p. 23-58.

69. Hilda SMITH, Reason's Disciples, op. cit., 59.

70. Miriam BRODY, op. cit., 54 .

71. Bridget HILL, op. cit., 43.

72. Miriam BRODY (ed.), op. cit., p. 57.

\section{ABSTRACTS}

Mary Astell (1666-1731) and Mary Wollstonecraft (1759-1797) dealt with the representation of women's status in domestic and political patriarchy as constructive, and proposing thinkers. They denounced women's status and submission, and criticised many aspects of patriarchy, seeing women as reasoning creatures and claiming that they should be treated as men are.

After a presentation of the writers and their works highlighting their common points and differences, the analysis of both writers' representations of women's status in domestic and political patriarchy examines particular aspects in law and social practices such as education and marriage. We finally focus on the constructive side of Astell and Wollstonecraft's criticism and on their purpose: to educate women not to please men but as rational creatures and to give enlightened women a better and more equal place.

Mary Astell (1666-1731) et Mary Wollstonecraft (1759-1797) exposèrent leurs vues sur le statut des femmes dans le patriarcat politique et domestique en effectuant des propositions constructives. Elles dénoncèrent le statut des femmes ainsi que leur soumission et critiquèrent maints aspects du patriarcat, les concevant comme des créatures capables de raison et revendiquant pour elles un traitement égal à celui des hommes.

Après avoir présenté les auteurs et leurs œuvres et mis en relief leurs points communs et leurs différences, on analyse la représentation du statut des femmes dans le patriarcat politique et domestique en s'attachant à deux points particuliers des pratiques sociales et juridiques, à savoir l'éducation et le mariage. On se concentre enfin sur l'aspect constructif des critiques de Mary 
Astell et de Mary Wollstonecraft et sur leur but : éduquer les femmes comme des créatures non pas destinées à plaire aux hommes mais dotées de raison et donner aux femmes éclairées une place plus juste et égale à celle des hommes.

\section{AUTHOR}

\section{GUYONNE LEDUC}

Université Charles-de-Gaulle Lille 3 